\title{
Physiological Adaptations and Behavioral Responses of Janitor Fish (Ancistrus sp. orange) to Warming Temperature
}

\author{
Julie S Berame* and Noel F Alfonso \\ Department of Biology, Philippines \\ Submission: December 04, 2018; Published: January 17, 2019 \\ *Corresponding author: Julie S Berame, Department of Biology, Philippines
}

Abstract

The study aims to determine the effect of high warming temperature on the behavioral responses of the Ancistrus sp. orange on the rates of ventilation, intake of food, and patterns of behavior at normal $\left(21{ }^{\circ} \mathrm{C}\right.$ to $\left.26{ }^{\circ} \mathrm{C}\right)$ and high temperature $\left(26+{ }^{\circ} \mathrm{C}\right)$ in the present warming scenario. The non-experimental and experimental data were running in a One-Way ANOVA in order to determine the significant difference in the effect of temperatures, rates of ventilation, intake of food, and patterns of behavior. Statistical analysis was performed at 0.05 level of significance. Based on the findings of the study, it found out that Ancistrus sp. orange showed resistance in heat stress but is it projected to go through any physiological impairment when they exposed longer into an increasing temperature. Their food intake has no significant difference with a p-value of .594, but behavioral changes and ventilation rates were significantly affected with the increased high temperature with a p-value of $.00)$.

Keywords: Janitor Fish (Ancistrus Sp. Orange); Warming Temperature; Adaptation; Behavioral Responses

\section{Introduction}

The janitor fish (Ancistrus sp. orange) is a decorative freshwater fish from Northern and Southern America that has been introduced to the aquatic habitats somewhere in America, Europe, and Asia [1] like Philippines. There ever-increasing trade is one of the most significant passageways for aquatic invasion $[2,3,4,5]$. Among of those ornamental fishes are the janitor fish of the family Loricariidae and genus Pterygoplichthys T.N. These fishes have established successful invasive populations throughout the world $[6,7,1,8,9,10]$. The Pterygoplichthys spp. has many collective names comprising armored catfishes, janitor fish, sailfin catfishes, plecos, glass cleaner catfishes, or sucker-mouth catfishes $[11,12,5]$. They have been documented from many water bodies and in many places where they become invasive type of species for more than two decades [13,14]. Pterygoplichthys spp. inhabits anthropogenically-modified aquatic habitats $[15,16]$. These fishes were able to endure varied fluctuations in flow systems of water $[9,17]$, they resist hypoxia due to structural modifications in their gut that allow them to take breaths air [18]. Their invasion as a non-native species was mainly determined with their capability to acclimate the physiochemical dynamics in their occupied territory [19]. Their janitorial skills, attracted by number of aquarists due to their distinct appearance, strange behavior, routine characteristics, appealing among the aquarists [20], and they grow fast that could be highly disruptive in small containers. As a result, they likely surpass the abilities of many hobbyists to contain them and are subject to release unintentionally that leads to environmentally unwise owners [21].
As mentioned in the conceptual model of the environmental impacts of Pterygoplichthys spp. it identifies that there is a severe effect to different groups of organisms (receptors) if they become irresponsibly managed because they might be a model to use in assessing environmental warming, dealing resources, and planning future research [4]. In a changing temperature nowadays, the tendency for rising temperatures may act like synergistic effects on water, which might be intensified when combined with effects [22]. Surface temperature is rising at an unprecedented rate since 1979 with the approximately mean global temperature increased to 0.13 0C per decade. As experienced, warming temperature becomes more penetrating, more recurrent, and will last for longer period in a tropical climate dynamic like Philippines. Nowadays, many fishes are sensitive to warmer temperature than those they usually experience in nature for the past decades. The increase of even $10 \mathrm{C}$ temperature may be able to have rapid effect on the geographical distribution and mortality rate of some aquatic fishes [23]. In fact, the rising of temperature is already affecting the abundance, distribution of species and compromising the entire ecosystem [24].

Generally, fishes like Pterygoplichthys spp. fishes are ectothermic, meaning their body temperature relatively detects with the surrounding environmental temperature that result to their increased metabolic rates. Their characteristics in a warming temperature [25] may be less severe in fishes; the peculiar characteristics of Pterygoplichthys spp. make them an 
interesting model for warming temperature researches [26]. In addition, there is already a growing interest that stress on the impact of warming temperature on water organisms, but there is no report for this concern, except in the findings in the aquaculture techniques of fishes. With this, the fundamental of this study point out that changing into warming temperature might affect to their physiological growth, feeding, behavior, reproduction, survival, and fish color $[27,28,5]$. So, in the present study, the Materials and Methods researcher attempts to observe the effects of the increasing thermal temperature on the rates of ventilation, feeding rates, and behavioral responses of Ancistrus sp. orange both in normal and high temperature for better understanding of the warming environment effect to the future expected conditions, which may support the development of new model in studying Ancistrus sp. orange on warming temperature scenarios $[29,30]$ of fresh water organisms as well.

\section{Fish Collection and Storing Conditions}

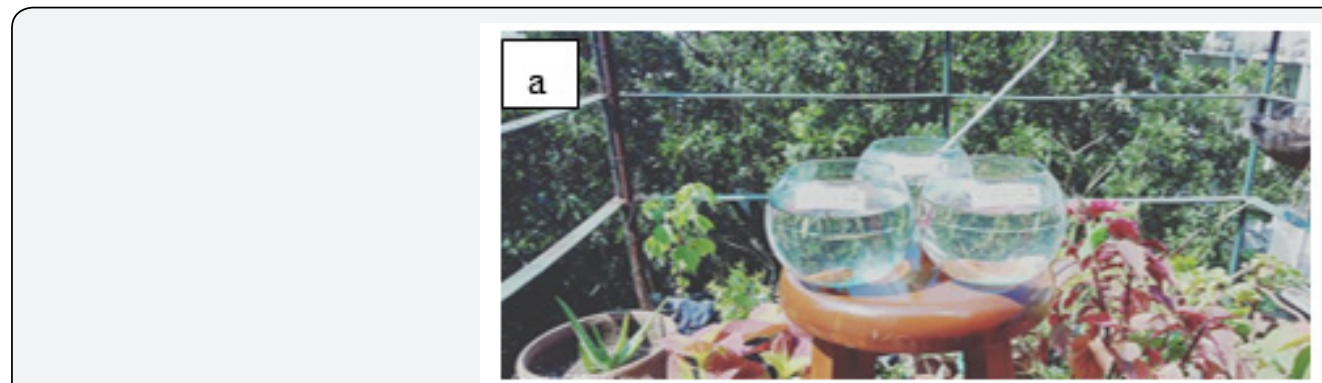

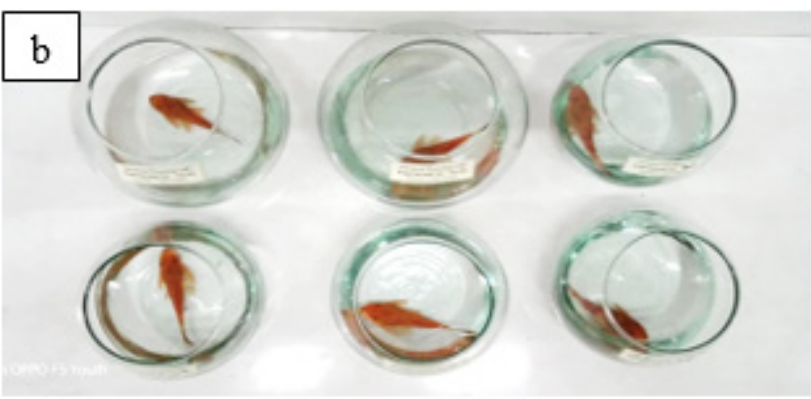

Figure 1: The experimental set ups of Ancistrus sp. orange. (a) Warm temperature; (b) Normal temperature.

Janitor fishes (Ancistrus sp. orange) were transported from an aquarium shop in Octomber, 2018. They were placed to the aquarium facilities in the laboratory and kept in normal temperature with $825 \mathrm{~mL}$ of water (Figure 1). Water parameters were normal temperature of $21{ }^{\circ} \mathrm{C}$ to $26{ }^{\circ} \mathrm{C}$, high temperature of $26+{ }^{\circ} \mathrm{C}$, and $\mathrm{pH}$ of 7.4. The Ancistrus sp. orange fishes were fed with fillet balls once a day, except for Sundays. The aquaria were cleaned after two days with $10 \%$ ( $82.5 \mathrm{~mL}$ ) of water changes were made. The janitor fishes (Ancistrus sp. orange) fishes were acclimatized to adapt water conditions. Afterwards, janitor fishes (Ancistrus sp. orange) were acclimatized to two different temperature set-ups:

i) The normal temperature $\left(21^{\circ} \mathrm{C}\right.$ to $\left.26^{\circ} \mathrm{C}\right)$

ii) The projected temperature that they may endure in the future. At the end of the experiments, the janitor fishes (Ancistrus sp. orange) were released in river without injuries.

Table 1: Ethogram of Ancistrus sp. orange pattern activities.

\begin{tabular}{|c|r|}
\hline Category & Behavioral Description \\
\hline Sucker-mouthing & The Ancistrus sp. orange uses their suckermouth to hold into solid substrates/surface. \\
\hline Swinging & The Ancistrus sp. orange sways its pelvic fin and bracing using their studded spines of their pectoral fins. \\
\hline Feeding & The Ancistrus sp. orange scrapes / rasps food from different substrates/surface and swallows the food. \\
\hline Inactivity & The Ancistrus sp. orange remains inactive most of the time in the glass floor / side. \\
\hline
\end{tabular}

\section{Food intake, ventilation rates and behavioral pattern}

Six janitor fishes (Ancistrus sp. orange) were placed individually in $825 \mathrm{~mL}$ in the glass bowl aquaria inside the laboratory. The 3 janitor fishes (Ancistrus $s p$. orange) were observed in a normal temperature $\left(21^{\circ} \mathrm{C}\right.$ to $\left.26^{\circ} \mathrm{C}\right)$ in the lab and the other 3 janitor fishes (Ancistrus sp. orange) were placed on a warming temperature $\left(26+{ }^{\circ} \mathrm{C}\right)$ outside the lab. The janitor fishes (Ancistrus sp. orange) were fed 5 fillet balls per day. Their feeding rates, ventilation rates, and activity patterns were determined with 2 different temperature set - ups $\left(21{ }^{\circ} \mathrm{C}\right.$ to $26{ }^{\circ} \mathrm{C}$ and $26+$ ${ }^{\circ} \mathrm{C}$ ). Acclimation to warming temperature was done through a 2 hour gradual increase in the water temperature. Ventilation of gill rates were counted before feeding based on their opencular beats per minute using a tally counter device. For their food intake, it was counted based on leftovers the following day since they are nocturnal. Their behavioral patterns were also observed on their ethogram (Table 1). 


\section{Statistical Analysis}

The statistical analysis used in the study was One-Way Analysis of variance (ANOVA) in order to determine the effect of temperature on food intake and ventilation rates of Ancistrus $s p$. orange. Qualitative analysis was also used in their behavioral patterns. The statistical analysis was performed in a significance level of 0.05 using SPSS version 20 software.

\section{Results and Discussion}

It is shown Table 2 that the mass and some physic-parameters of the distilled water used in the controlled and uncontrolled groups of Ancistrus sp. orange. Based on the result, there was a mass increased in the controlled group of at least. $3 \mathrm{~g}$ within the period of the study for 2 Ancistrus sp. orange and 1 has a decreased of .1g. As documented, fish 2 in the controlled group failed to consume enough food fillets in the first 2 days as an apparent factor

Table 2: Mass and physico-parameters of water used in the experiment.

\begin{tabular}{|c|c|c|c|}
\hline Ancistrus sp. orange & Mass & Water Quality (pH) & Dissolved Oxygen (D0) \\
\hline F1 (N temp) & $+.3 \mathrm{~g}$ & -1.47 & -2.18 \\
\hline F2 (N temp) & $-.1 \mathrm{~g}$ & -1.57 & -0.61 \\
\hline F3 (N temp) & $+.3 \mathrm{~g}$ & -1.41 & -0.48 \\
\hline F1 (H temp) & $-.8 \mathrm{~g}$ & -1.45 & -1.58 \\
\hline F2 (H temp) & $*$ & -1.44 & -0.74 \\
\hline F3 (H temp) & $*$ & \\
\hline
\end{tabular}

Dissolved oxygen (DO) was tested with the DO meter. Based on literatures, each organism has its own DO tolerance range. Reading suggests that if the temperature raised to $21{ }^{\circ} \mathrm{C}$, there would be $8.68 \mathrm{mg} / \mathrm{L}$ DO (Silencing, 2018) plus warm water holds less oxygen in water with level below $1 \mathrm{mg} / \mathrm{L}$ are considered hypoxic and usually devoid of life. As presented in Table 1, there was a slight increase in water DO (-) of 4 fishes which is a desirable level

\section{Effects of normal and high temperature in their food intake}

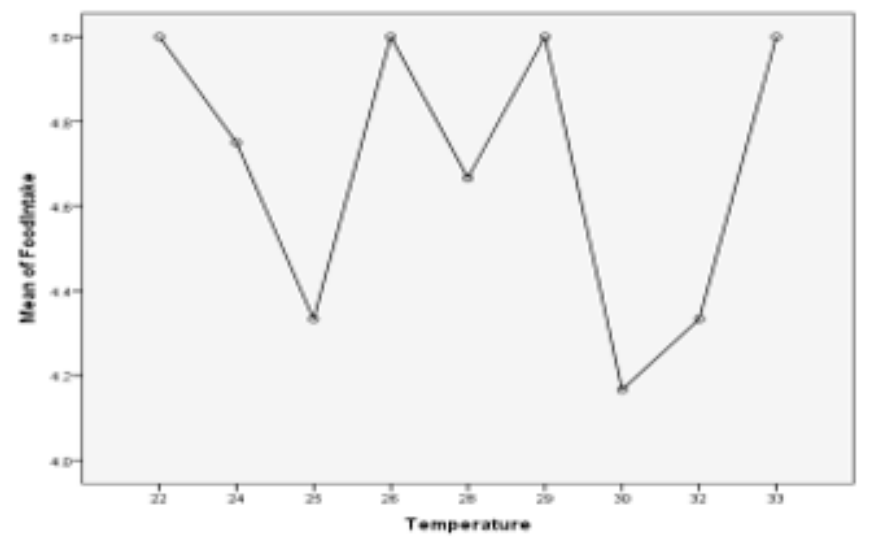

Figure 2: Impact of both normal and high temperatures in the food intake in controlled and experimental set-ups of Ancistrus sp. orange.

As seen below Figure 2, the lowest temperature recorded in the controlled set-up of Ancistrus sp. orange was 22 0C and the highest temperature was $33{ }^{\circ} \mathrm{C}$. As shown below, there were 2 fishes did not eat their food fillets in the early part of the assays to consider for its mass decreased. For the uncontrolled group, fish 1 has only survived until the end of the study with a mass decreased of $.8 \mathrm{~g}$. The rest, they did not survive. This decreased in mass may considered these factors such as unadjusted to the new environment, sudden changes in $\mathrm{pH}$, abrupt changes in water temperature, insecurity if they are not comfortable in their surroundings, lack of sufficient oxygen, exposed to sunlight or physical stress. In this study, distilled water was used because tap water is more acidic ( $\mathrm{pH}$ of 5.8) compared to distilled water with a $\mathrm{pH}$ of 7. This $\mathrm{pH}$ is desirable to consider when it comes to this kind of study. The $\mathrm{pH}$ meter was used to determine the quality of the water. As shown Table 2, there was a decreased in the water quality after 2 days with a mean of at least -1.45 . This shows that water quality was deteriorating if exposed into this kind of water condition. With this, fishes will not survive because their home is very limited plus it could be contaminated easily with impurities in the water.

for them to live or survive except for 2 fishes that had decreased in dissolved oxygen which they did not survive. In addition, when water temperature increases, the dissolved oxygen (DO) level will decrease that can cause stress, less chance of getting oxygen, too low level of dissolved oxygen, or even death for many fishes in the water ecosystem. 
consumed their food fillets. In my claimed, the first 2 days from the start of the assay, fish 2 has disturbed the new environment. In contrast, like most fishes, Ancistrus sp. orange is ectothermal and their body temperature fluctuates with external temperature. In the experiment, 2 Ancistrus sp. orange fishes were affected that high water temperature has harmful effects on several features of Ancistrus sp. orange life in an artificial ecosystem. The increase of water warming temperature has slight changes in their food intake and activity patterns. In addition, the lack of differences in their food intake and behavior in 2 experimental set-ups with varied water temperature scenarios may be explained by the referred ability of Ancistrus sp. orange to adapt to different temperature fluctuations as they endure in their ecosystem. So, both factors if combined might act to decline and affect fish survival [22].

\section{Effects of normal and high temperature in their venti- lation rates}

The effect of warming water temperature was expected to accompany by an increase in their ventilation rates. As shown Figure 3, there was a significant increase in their rates of ventilation of 800.67 mean difference beats compared to normal water temperature. As indicated, the highest temperature recorded was $33{ }^{\circ} \mathrm{C}$ and has reached to 365 beats (Fish 1) based in their opercular beats using a tally counter per minute after it acclimatized for 2 hours in a warming water temperature when exposed into the sunlight. As observed, the data suggest that such temperature $\left(26+{ }^{\circ} \mathrm{C}\right)$ is already beyond the temperature tolerance or critical level. This indicates that fitness and survival level will be life-threatening of the aquatic species due to oxygen deficiency [22] and higher temperature results in less dissolved oxygen in the water. It demonstrates that Ancistrus $s p$. orange significantly affected by warming water temperature. Their opercular beats were become faster when exposed in a rising temperature of $26+{ }^{\circ} \mathrm{C}$. Based on the literatures, when water will become heated, like exposing into the sunlight or near to a thermal source, water temperature increases, then the dissolved oxygen level will decrease that can cause strain or even death for many fishes, most importantly for the survival of aquatic animal like fishes. This specifies that both factors might thus act as synergistic stressors (combined effects) and be overwhelming to the cardiorespiratory processes that might suffer a decline in the efficiency to sustain muscular activity, growth at a critical point, and the survival of the fishes [22] even they are highly adaptable to different environments [15].

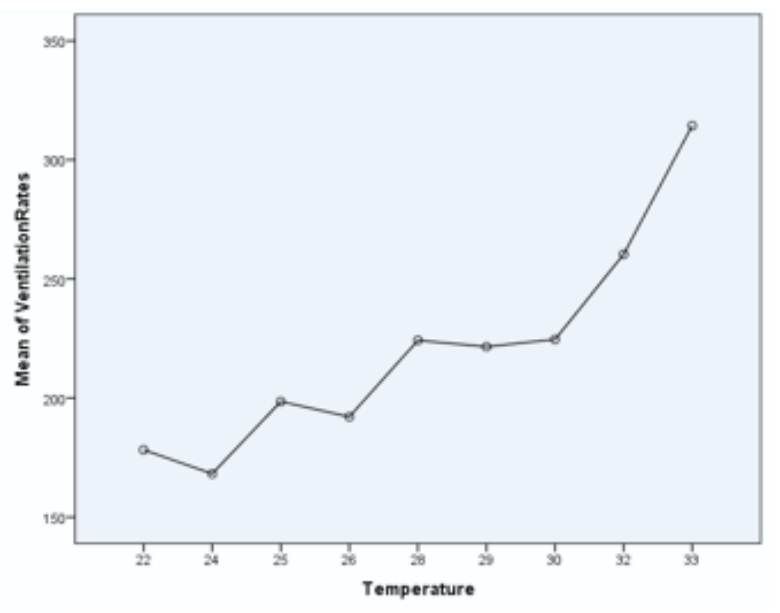

Figure 3: Impact of high temperature in the ventilation rates of Ancistrus sp. orange.

Table 3: Results of One-Way ANOVA Analysis on the effect of high water temperature of Ancistrus sp. orange in relationship to their food intake and ventilation rates.

\begin{tabular}{|c|c|c|c|c|c|c|}
\hline & & Sum of Squares & df & Mean Square & $\mathbf{F}$ & Sig. \\
\hline \multirow{3}{*}{ Food Intake } & Between Groups & 8.706 & 8 & 1.088 & .812 & .594 \\
\hline & Within Groups & 108.583 & 81 & 1.341 & & \\
\hline & Total & 117.289 & 89 & & & \\
\hline \multirow{2}{*}{ Ventilation } & Between Groups & 98448.50 & 8 & 12306.06 & 8.284 & .000 \\
\hline & Within Groups & 120321.98 & 81 & 1485.457 & & \\
\hline Rates & Total & 218770.48 & 89 & & & \\
\hline
\end{tabular}

Data analysis on the food intake and ventilation rates in normal and high temperature (Table 2). As shown in Table 2, the analysis on the food intake and ventilation rates when exposed to normal and high water temperatures. As presented above, the food intake of Ancistrus sp. orange has no significant correlation to warming temperature. The p-value of food intake is .594 which failed to reject the null hypothesis with the significant level of .05. Unexpectedly, their food intake remained almost unchanged with the increasing temperature except fish \#2 which it presumed not totally adapted the new environment. Hence, their activity patterns were also expected to change in high temperature. The lack of differences in their food intake in various temperature 
scenarios may be explained by the referred ability of the fishes to adapt temperature fluctuations as they endure in their newly adapted habitat. As observed, Ancistrus sp. orange were very behave most of the time and based on literatures, they are very active in night time as nocturnal species. In contrast, the Ancistrus sp. orange ventilation rates were significantly affected by warming temperature. As expected, their ventilation rates (Table 3) has a p-value of .00 less than the significant value of .05 which leads to reject the null hypothesis. As observed, their opercular beats relatively increased in rising temperature of $26+{ }^{\circ} \mathrm{C}$. Based on record, the highest opercular beats recorded were 365 beats at 33 ${ }^{0} \mathrm{C}$ temperature (Figure 3 ) as well as their activity patterns. When temperature exceeded beyond the normal degree, Ancisftrus $s p$. orange started moving when directly exposed into sunlight, upraised and expand their pelvic fins, and swam up to the surface water to get oxygen.

In general, Ancistrus sp. orange showed to be sensitive to warming water temperature. Based on study, the abrupt decline in their thermal sensitivity when they exposed to upper $26+{ }^{\circ} \mathrm{C}$ suggests that such temperature is already above their tolerance level which leads to compromise their fitness and survival [3] because warming temperature increases their oxygen demand that may result to less dissolved oxygen in water. In this situation, water quality becomes too low in oxygen leading the organisms to die. Moreover, it arose that warming temperature can cause heat stress to water organisms like fishes and are projected to undergo physiological impairment and behavioral changes relative to their growth, survival, and environmental disturbance [31]. Their limited environment will become harmful in a warming temperature scenario since their environment is so limited and they have no capacity for possible migrations in order to reproduce their species [32-40].

\section{Conclusion}

In conclusion, the researcher provides evidence that Ancistrus $s p$. orange was affected with heat stress and is likely to suffer physiological impairment and abrupt changes of their behaviors in the anticipated increase temperature. In addition, they might experience metabolic imbalance with likely significances for their endurance to warning temperature and may be enable to ought certain level of adaptability and resilience to environmental disturbance, but they may suffer and possibly may not survive. So, owners might be sensitive enough to consider their ecosystem because these fishes are charismatic to have the potential to become symbols of protection. Their unique aspect turns them into a flagship species for aquarists' conservation issues to understand their vulnerabilities and their responses to future scenario for warming temperature.

\section{Acknowledgment}

The author expresses his appreciation to Dr. Noel F. Alfonso of De La Salle University for his expertise and excellent accommodation in Advanced Physiology Course.

\section{References}

1. Fuller P, Nico L, Williams G (2002) Nonindigenous fishes introduced into inland waters of the United States. American Fisheries Society, Special Publication 27: 435-441.

2. Miranda P, Coelho F, Tomé A, Valente M (2002) Climate change in Portugal: scenarios, impacts and adaptation measures - SIAM Project. Gradiva, Lisboa p. 27-83.

3. Pörtner, H, Farrell A (2004) Physiology and Climate Change. Science New Series 322: 690-692.

4. Scott G, Sloman K (2004) The effects of environmental pollutants on complex fish behavior: integrating behavioral and phy-siological indicators of toxicity. Aquatic Toxicol 68: 369-392.

5. Singh A, Ansari A (2014) Emerging alien species in aquaculture: prospects and threats. Journal of Aquatic Biology \& Fisheries 2: 32-41.

6. Armando T, Ramon R, Enrique A (2007) Amazon sailfin catfish Pterygoplichthys pardalis (Loricariidae), another exotic species established in south-eastern Mexico. Southwestern Naturalist 52: 141144 .

7. Chavez H, Casao E, Villanueva E, Paras M, Guinto M, et al. (2006) Heavy metal and microbial analyses of janitor fish (Pterygoplichthys spp) in Laguna de Bay, Philippines. J of Envirl Sci and Mngt 9: 31-40.

8. (2007) IPCC, Intergovernamental Panel on Climate Change: The fourth assessment report of the intergovernmental panel on climate change (IPCC). Cambridge University Press, Cambridge, UK.

9. Muralidharan M (2017) Do alien species matter? Impacts of invasions in Indian freshwater systems and challenges in management. International Journal of Aquatic Biology 5(2): 114-127.

10. Perry A, Low P, Ellis J, Reynolds J (2015) Climate change and distribution shifts in marine fishes. Science 308: 1912-1915.

11. Daniels R (2006) Introduced fishes: a potential threat to the native freshwater fishes. Journal of the Bombay Natural History Society 103: 346-348.

12. Knight J (2010) Invasive ornamental fish: A potential threat to aquatic biodiversity in peninsular India. Journal of Threatened Taxa 2: 700704.

13. Lopez-Fernandez H, Winemiller K (2005) Status of dionda diaboli and report of established populations of exotic fish species in lower San Felipe Creek. Southwestern Naturalist 50: 246-251.

14. Raghavan R, Prasad G, Kumar A, Sekharan M, Pereira B, et al. (2009) When pets become pests - exotic aquarium fishes and biological invasions. Current Science 97: 474-476.

15. Lin Q, Lin J, Huang L (2009) Effects of substrate color, light intensity and temperature on survival and skin color change of Hippocampus erectus Perry. Aquaculture 298: 157-161.

16. Nico L, Martin T (2016) The South American suckermouth armored catfish, Pterygoplichthys anisitsi (Pisces: Loricariidae), in Texas, with comments on foreign fish introductions in the American Southwest. Southwestern Naturalist 46: 98-104.

17. Walsh J, Carpenter S, Vander Zanden M (2016) Invasive species triggers a massive loss of ecosystem services through a trophic cascade. Proc Natl Acad Sci USA 113: 4081-4085.

18. Da Cruz A, Da Silva H, Lundstedt L, Schwantes A, Moraes G et al. (2013) Air-breathing behavior and physiological responses to hypoxia and air exposure in the air breathing loricariid fish, Pterygoplichthys anisitsi. Fish Phygyy and Bio 39: 243-256.

19. Kennedy V, Twilley R, Kleypas J, CowanJr J (2015) Coastal and marine ecosystems and global climate change: Potential effects on U.S. resources. Pew center on global climate change: Arlington, Virginia. 
20. Rogers D, Fletcher S, Saunders J, Herbert R, Roberts C, et al. (2012) Description of the 977 ecosystem services provided by broad-scale habitats and features of conservation importance. Arine Conservation Zone Project Area. Natural England Commissioned Reports 088.

21. Trajano E (2013) Habitat and population data of troglobitic armored cave catfish, Ancistrus cryptophthalmus, CentralBrazil (Siluriformes: Loricariidae). Env l Bio of Fishes 62(1): 195-200.

22. Piazzini S, Lori E, Favilli L, Cianfanelli S, Vanni S, et al. (2010) Invasion note: a tropical fish community in thermal waters of southern Tuscany. Biological Invasions 12: 2959-2965.

23. Jones R, Weyl O, Swartz E, Hill M (2013) Using a unified invasion framework to characterize Africa's first Loricariid catfish invasion. Biological Invasions 15: 2139-2145.

24. Brierley A, Kingsford M (2014) Impacts of climate change on marine organisms and ecosystems. Curr Biol 19: 602-614.

25. Reis D, Frehse F, Bezerra L (2016) Fish biodiversity and conservation in South America. J of Fish Bio 90: 1182-1190.

26. Ortega A, Murillo O, Pimienta M, Sterling J (2015) Characterization of the native fish fauna of rivers in the upper basin of the Rio Cauca department of Valle del Cauca. Corporacion Autonoma Regional del Valle del Cauca, CVC p. 83.

27. Foster S, Vincent A (2015) Life history and ecology of seahorses: implications for conservation and management. J Fish Biol 65: 1-61.

28. Koldewey H, Martin Smith K (2010) A global review of Hippocampus erectus Perry aquaculture. Aquaculture 302: 131-152.

29. Bessa E, Trajano E (2013) Light reaction and cryptobiotic habits in armored catfishes, genus Ancistrus, caves in Central and North west Brazil (Siluriformes: Loricariidae). MemoiresdeBiospe ologie 28: 2937.

30. Rao K, Sunchu V (2017) A report on Pterygoplichthys pardalis Amazon sailfin sucker mouth catfishes in freshwater tanks at armored catfish salinity tolerance. International Journal of Fisheries and Aquatic Studies 5: 249-254.

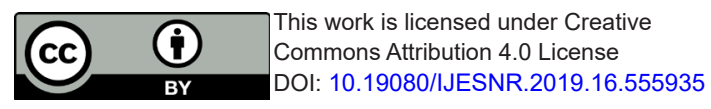

31. Roessig M, Woodley M, Cech J, Hansen L (2004) Effects of global climate change on marine and estuarine fishes and fisheries. Rev Fish Bio Fish 14(2): 251-275.

32. Bichuette M, Trajano E (2015) Population density and habitat of an endangered cave fish Eigenmannia vicentespelaea Triques, Central Brazil. Neotropical Ichthyology 13(1): 113-122.

33. Gibbs M, Kurth B, Bridges C (2013) Age and growth of the loricariid catfish Pterygoplichthys disjunctivus in Volusia Blue Spring, Florida. Aquatic Invasions 8: 207-218.

34. Kestrup Å, Ricciardi A (2014) Influence of conductivity on the life history traits of exotic and native amphipods in the St. Lawrence River. Fundamental and Applied Limnology 176: 249-262.

35. Meena M, Sundaramanickam A, Ajith Kumar T (2016) Occurrence of a Pterygoplichthys disjunctivus population in Cauvery River System, Tamil Nadu, South India. International Journal of Fisheries and Aquaculture 8: 62-66.

36. Russell I (2010) Mass mortality of marine and estuarine fish in the Swartvlei and wilderness lake systems, Southern Cape. South Afr J of Aquat Sci 20: 93-96.

37. Sandilyan S (2016) Occurrence of ornamental fishes: a looming danger for inland fish diversity of India. Current Science 110(11): 2099-2104.

38. Sheng J, Lin Q Chen Q, Gao Y, Shen L, et al. (2016) Effects of food, temperature and light intensity on the feeding behavior of the threespot Hippocampus trimaculatus Leach. Aquaculture 256: 596-607.

39. Smith S, Bell G, Bermingham E (2004) Cross-cordillera exchange mediated by the Panama Canal increased the species richness of local freshwater fish assemblages. Proceedings of the Royal Society London B: Bio Sci 271: 1889-1896.

40. Welcomme R, Vidthayanom C (2014) The impacts of introductions and stocking of exotic species in the Mekong Basin and policies for their control. MRC Technical Paper No. 9, Mekong River Commission, Phnom Penh p. 35.

Your next submission with Juniper Publishers will reach you the below assets

- Quality Editorial service

- Swift Peer Review

- Reprints availability

- E-prints Service

- Manuscript Podcast for convenient understanding

- Global attainment for your research

- Manuscript accessibility in different formats

(Pdf, E-pub, Full Text, Audio)

- Unceasing customer service

Track the below URL for one-step submission https://juniperpublishers.com/online-submission.php 